I-Pop: International Journal of Indonesian Popular Culture and Communication

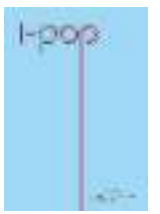

Vol. 1(1) pp. 41-62, (2020) DOI: I0.36782/i-pop.vlil.28

\section{Iwan Fals, Music, and the Voice of Resistance}

\author{
Muhammad Yusran Darmawan ${ }^{*}$
}

\begin{abstract}
This article is based on an assumption that there is a connection between popular music and the political situation in Indonesia. A singer has a function as a political actor, especially in the way these performers use music as a social weapon or tool -and even sometimes as a call to change, challenge or overthrow the existing government or socioeconomic conditions that they consider to be unjust systems. The purpose of this paper is to give an explanation about the life of Iwan Fals as a contemporary hero who inspires many people to be critical of authority. He has always been the voice of Indonesia's grassroots movement since the New Order era, but until now, he has preferred not to be its formal leader. He just keeps doing what he does best - singing and cheering - and maintaining the qualities of his song and conviction that keeps his fans loyal to him. Under the New Order, control of the arts and media by the government was mixed and inconsistent, but generally, Indonesia enjoyed a thriving and vibrant artistic scene, including music. Between the mid-1960s and 1990s, Indonesia developed a wide variety of popular music styles, some of which proved to be conducive and supportive to sociopolitical comments and critiques. Popular music became a major component of the background for daily life. In Indonesia, popular music became a tool of resistance to the government. Iwan Fals played an important role in this resistance.
\end{abstract}

Keywords

Iwan Fals, pop music, history, New Order, rebellion

To cite this article ( $7^{\text {th }}$ APA style)

Darmawan, M. Y. (2020). Iwan Fals, Music, and the Voice of Resistance. I-Pop: International Journal of Indonesian

Popular Culture and Communication, I(I), 4I-62. http://doi.org/I0.36782/i-pop.vlil.28

\section{INTRODUCTION}

Oppression and abuses of power

Are too numerous to mention

Stop, stop, don't go on

We're fed up with greed and uncertainty

-- Iwan Fals, "Demolish", a hit song of 1989

Each period has its own history. Each period has its own heroes. In 1999, the Indonesianist
Benedict Anderson wrote that what Indonesian people called "reformasi" in 1998 had actually occurred in early 1900. Since that period, there have been many heroes who raise the national awakening. Thus, what is happening today is similar to what happened in the past.

'IPB University, Bogor, Indonesia

*Corresponding author: yusrandarmawan@gmail.com 
Ben Anderson said that Indonesia had given birth to many heroes. They are Dr. Sutomo, Natsir, Tan Malaka, Kartini, Haji Misbach, Pramoedya Ananta Toer, Yap Thiam Hin, Sudirman, Roem, Sukarno, Hatta, Armijn Pane, Sudisman, Haji Dahlan, Hasjim Asj'ari, and more. In his article, he asked a question: who is the hero in contemporary Indonesia? Which person is worth admiring in modern Indonesia?

$\mathrm{He}$ asked this question to many Indonesian students in Cornell at that time. He wanted to compare about present and future figures in Indonesian history. Most of the students didn't know how to respond this question. Anderson hoped that they will mention one from the many names that are mentioned above. But he was questioning when the students mentioned Iwan Fals as their hero. He said: "Is not this rather terrifying?" I

I assume that not everyone understands about the contribution of Iwan Fals to social change in Indonesia. Maybe Anderson did not understand that through Iwan Fals' songs, Iwan Fals always talks about the sad social reality of Indonesia. Anderson's view may reflect the opinion of many people who think popular music is not important.

As noted by Lockard (1998), there is always a connection between popular music and the political situation in Southeast Asia. Lockard believes that a singer has a function as a political actor, especially in the way these performers use music as a social weapon or tool - and even sometimes as a call to change, challenge or overthrow the existing government or socioeconomic condition that they consider as unjust systems. In this context, Iwan honestly speaks about poverty, prostitution, government corruption, rising prices, and also public representatives who always sleep at the parliamentary hearing. $\mathrm{He}$ also played an important role to kindle the spirit of reform of Indonesian students during reformasi period. ${ }^{2}$

I still remember that era in 1997, when I

was a freshmen student at Hasanuddin University at Makassar. At that time, Indonesia and other Southeast Asia countries were hit by the monetary crisis. Everywhere, prices soared. In all cities, protests continued, requesting President Soeharto to step down from the presidency.

Almost every day, I always lead
Hasanuddin University students to demonstrate. Unfortunately, there were not many students interested to join our demonstration. Most of them just watched us marching in the streets. At that time, the New Order regime was still powerful. Many activists were kidnapped and killed by the military. One day, me and other student activists had an initiative to invite the living legend of Indonesian music, Iwan Fals, to play.

In 1997, Iwan Fals came to Hasanuddin University. He came as a member of Kantata Takwa band with the poet W.S. Rendra, the musician Sawung Jabo, and the businessman Setiawan Djody. They sang critical songs about the government. The students hoped that Iwan would sing Bongkar (demolish) and Bento, two powerful songs that we always sang in our demonstrations.

Then, Iwan sang Bongkar and Bento. The songs ignited the spirit of thousands of Makassar students. After that time, most university students joined us in every demonstration. Hundreds of students went to Jakarta and joined with thousands of other students to demonstrate in front of the House of Representatives. Iwan Fals and his band traveled to many areas and sang his critical songs. Finally, our effort paid off. On May 2I, 1998, Soeharto resigned as President of the Republic of Indonesia.

For me, Iwan Fals is a contemporary hero who inspires many people to be critical of the authority. Iwan Fals has always been the voice of Indonesia's grassroots movement since the New Order era, but until now, he has preferred not to be its formal leader. He just keeps doing what he does best -singing and cheering-and maintaining the qualities of his song and conviction that keeps his fans loyal to him. 


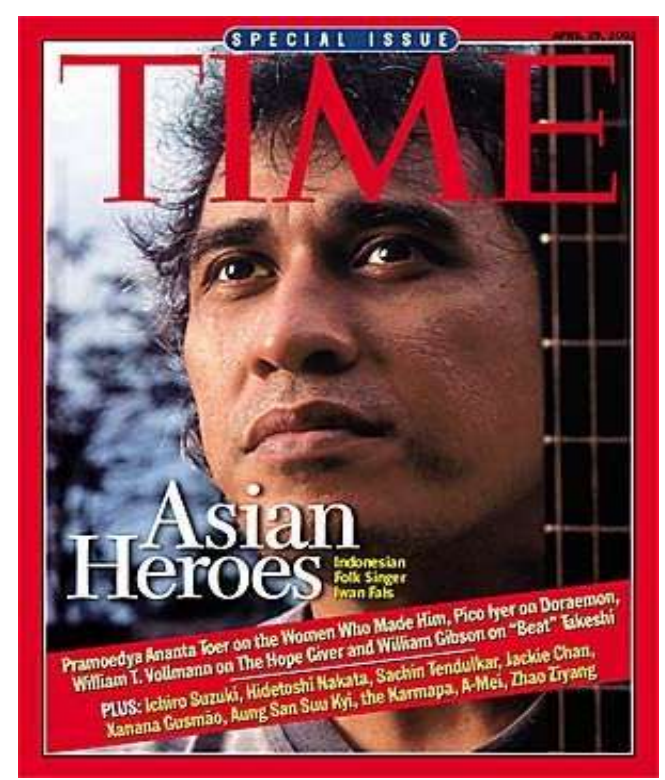

Figure I. Iwan Fals in Time (source: timurangin.com)

In 2002, Time magazine named Iwan Fals as the Asian Hero. ${ }^{3}$ In this edition, there were only two Indonesians in the list. They were Iwan Fals and novelist Pramoedya Ananta Toer. Their profiles were put together with the profiles of other Asian leaders such as the famous Hong Kong actor Jackie Chan, the Burmese prodemocracy leader Aung San Suu Kyi, the Tibetian monk, Karmapa Lama, and the East Timorese leader, Xanana Gusmao. Interestingly, Iwan Fals picture became the Time magazine's cover. In the article entitled "Iwan Fals Sings a Timeless Message of Justice for All", Time noted:

"Here's why Iwan Fals matters: because boy bands don't take on dictatorships. They don't stand up when everyone else is hunkering down. They don't put to song what others are afraid to put in print. Pop stars should give a damn-when they do, remarkable transformations are possible".

Time also noted that Iwan Fals concert was the most widely attended concert in Indonesia. Time noted: "He's the voice of the people. And he has been a thorn in the side of those who would abuse power."
Another prominent magazine focusing on music, politics and lifestyle, Rolling Stone, also wrote a comprehensive report about Iwan Fals. This magazine made a list of the $I 50$ best songs in the history of Indonesian music. Iwan Fals' song Bongkar (demolish) became the best song on the list. Two other songs such as Guru Oemar Bakri and Bento were also in the top ten. According to Rolling Stone, Iwan was a musician who inspired many people with the power of his lyrics.

Iwan Fals, nevertheless, is not alone in the ranks of musicians that voice critical songs in the history of Indonesian music. In the late 1940s, some nationalists controlled several radio stations during the Indonesian revolution and employed that advantage to spread their message. They modified keroncong as a weapon, with many 'lagu perjuangan' (redemption songs) written in this kind of genre and broadcasted them on revolutionaries-controlled radio stations. Hence keroncong came to characterize not just lower-class but also nationalist aspirations. Even today most of these songs are performed in keroncong style. The nationalist songs are known as keroncong revolusi (revolutionary keroncong) and deal with issues of freedom and independence. One of the bestknown songs was "keroncong merdeka"

During the 1950s and early 1960s, Indonesia was led by the charismatic President Soekarno, the founding father of Indonesian independence. In this era, Brigadier General Rudi Pirngadie, a veteran of the revolution occasionally named "General Keroncong", tried to create a modernized (and somewhat westernized) type that could serve as 'a concrete symbol of nationalist ideology.' Sukarno supported Pirngadie's attempt to create a national music for international consumption.

During the unrestrained Sukarno era, however, keroncong gradually faded in fame, seen by many as overly mellow (even insipid) and ironically, given its origins - bourgeois. In this era, a new form of proletarian theater called ludruk became widespread in some cities in Java; 
the closely related art form, ludruk was also established in Madura. The styles were deliberately crude compared to the elite wayang. Mixing music, comedy, and satire, the ludruk performance generally portrayed difficulties and issues of modern culture, including social criticism and problems of slum dwellers.

Under the New Order, control of the arts and media by the government was mixed and inconsistent, but generally, Indonesia enjoyed a booming artistic scene -including music. Between the mid-1960s and 1990s, Indonesia established a wide diversity of popular music styles, some of which proved favorable and supportive to socio-political comments and critiques. Popular music became a major constituent of the background for daily life (Lockhard 1998, p. 78).

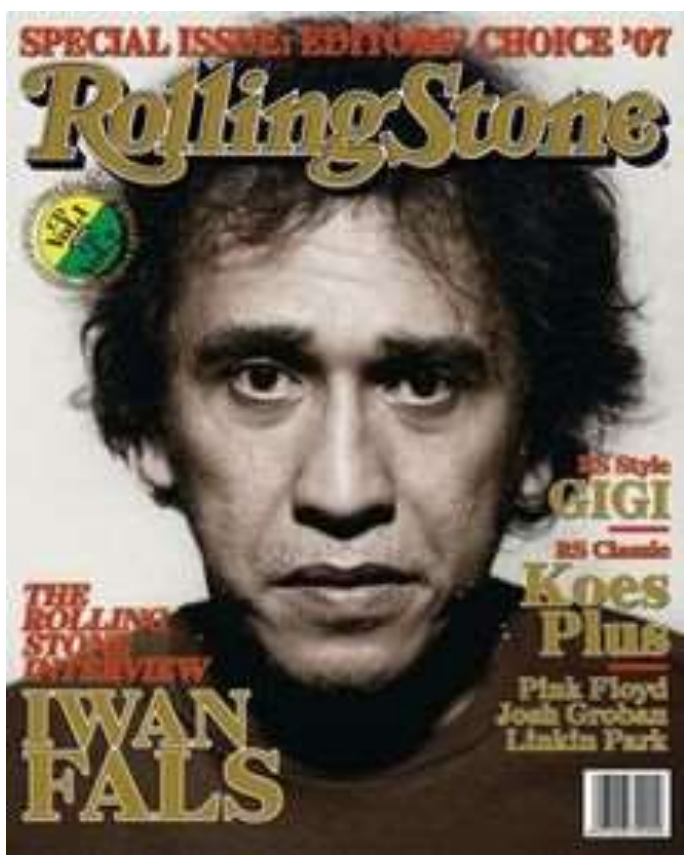

Figure 2. Iwan Fals in Rolling Stones (source: id.wikipedia.org)

I am interested to see how pop music became a medium of resistance in the repressive New Order situation. Through their lyrics, musicians tried to illustrate their ideas about politics and corruption. Even though the music industry was based in Jakarta, there were some musicians who produced critical songs about government in many regions. The four cities that became the centers of critical pop music in Indonesia were Jakarta, Surabaya, Bandung, and Yogyakarta. Musicians in these cities became icons of protest in the era of New Order.

In Jakarta, one of the critical musicians was Mogi Darusman (1947-2007) Mogi appeared with his song Rayap-Rayap (termites) and Koruptor (corruptor). ${ }^{4}$ Mogi's song is a critique of an official of the New Order who became a corruptor. He wrote this song with Teguh Esha, the author of the novel Ali Topan Anak Jalanan. The melody of the song is taken from the song The Cats She Was Too Young that was written by Piet Veerman, one of Mogi's friends in Europe. Mogi's father is a diplomat who spent his life in European countries. Although his father was part of the New Order, he strongly criticized the government. The New Order regime placed Mogi in the opposition side. He was often detained by police. His album was banned. He also was banned from the stage because the song was considered an insult to President Soeharto.

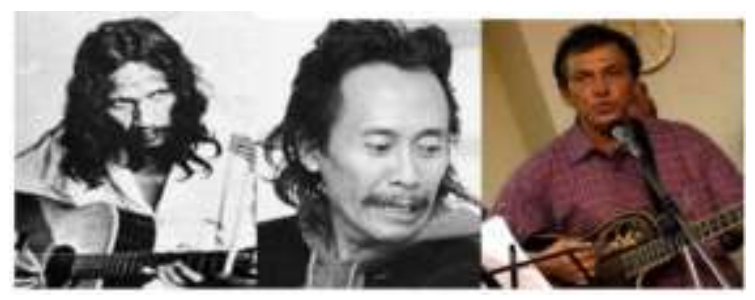

Figure 3. From Left to Right: Gombloh, Leo Kristi, Franky Sahilatua (source: timur-angin.com)

In Surabaya, critical pop musicians included Gombloh (1948 - 1988), Leo Kristi, and Franky Sahilatua (1953-20I I). They began their presence in the early of 1980s. Gombloh was a true ballad songwriter who joined with a group called Leom Trees who paid homage to art rock/ orchestral rock called Lemon Tree. His music was influenced by ELP and Genesis. Leo Kristi and Franky Sahilatua also became members of this group. Gombloh often depicted 
everyday life through songs like Doa Seorang Pelacur (A Pray of A Prostitute), Kilang-Kilang (Factories), Poligami (Poligamy), Nyanyi Anak Seorang Pencuri (The Song of a Thiefs Son), Selamat Pagi Kotaku (Good Morning My City). His lyrics were considered poetic and mysterious. As a ballad singer, Gombloh often wrote songs about the environment. One of them is Berita Alam (The Earth News), more popularly known as Kembalikan Alamku (My Sustainable Earth). Gombloh also produced love songs that tend to be "eccentric", much like the work of Iwan Fals or Doel Sumbang. One example is Lepen ("culverts" in the Javanese language, but here is an abbreviation of "short jokes").

The theme that made his songs become memorable is nationalism. His nationalism songs are Dewa Ruci (The God of Ruci), Gugur Bunga (The Flowers Autumn), Gaung Mojokerto Surabaya (The echoes of Mojokerto to Surabaya), Indonesia Kami - Indonesiaku Indonesiamu (Our Indonesia-My Indonesia-Your Indonesia), and Bung Karno, the story of Soekarno as the founding father of Indonesia. His song Kebyar Kebyar was sang by many students during the movement before the fall of General Soeharto in 1998.

The idealistic lifestyle of Gomboh inspired other musicians such as Leo Kristi. Leo's musical journey moved even further in 1969, when he joined in a band called Lemon Trees with musician Gombloh, who was his friend at the School of Architecture at the Surabaya Technology Institute (ITS). Then, Leo left this band to launch his solo music career, moving from one place to another to sing, including in restaurants, the Goethe Institute and IndonesiaAmerica Foundation (LIA). In 1975, he released his first album, Nyanyian Fajar (The Song of the Dawn) and over the next 20 years, nine more albums followed.

Leo Kristi musical concept is the 'People's Concert'. Although similar nationalist musicians like Gombloh might have gained more popularity, Leo won cult status. He has many loyal fans scattered across the country, with many of them founding their own music groups influenced by Leo's style. But then how can a musician like Leo who seldom puts out records (his last album, Tembang Lestari, was released in 1995) maintain such a solid fan base? Simply, Leo travels a lot, meets people and interacts with them, which means he builds a certain attachment among his listeners.

Another famous musician in Surabaya was Franky Sahilatua. He was one of the activists who often criticized the government. Although he was born in Ambon, Maluku, in 1953, he started his career in Surabaya. His music was country/ folk music that was influenced by John Denver and Joan Baez. He started his music career when he joined with the Lemon Trees with Gombloh and Leo Kristi. Then, he also sang with his sister Jean Maureen Sahilatua. His name became very popular when he was asked by the author Teguh Esha to sing the songs in the album Balada Ali Topan Anak Jalanan (the ballad of Ali Topan, a street child).

Aside from being a singer, Franky was an activist who joined the pro-democracy movement. Together with Iwan Fals, he has contributed to the process of denouncing Soeharto as the president of Indonesia. Together, they wrote the song Di Bawah Tiang Bendera (Under the Flag Pole) in 1997 to describe the military raid on the office of the Indonesian Democratic Party -Partai Demokrasi Indonesia. This song was later sang by students in many demonstrations against Soeharto. Another song with Iwan Fals is Orang Pinggiran (Marginal People) which highlights the poor citizens' life. Franky also collaborated with poet Emha Ainun Najib 6 in Perahu Retak (The Cracked Boat) that described the Indonesia situation in the early part of 1998.

In Yogyakarta, a prominent musician was Ebiet G. Ade. Ebiet's father was a civil servant (PNS), and his mother was a cloth merchant in Banjarnegara, Central Java. At first he wanted to be a religion teacher, but his destiny took him to Yogyakarta to be active in the Pelajar Islam Indonesia, (Indonesian Muslim Students -PII), 
one of the leading student organizations. He joined with several young artist groups at Yogyakarta in 197I. He made friendship with many famous critical artists such as Emha Ainun $\mathrm{Najib}^{5}$ (poet), Eko Tunas (author) ${ }^{6}$, and EH Kartanegara (author) ${ }^{7}$.

At first, Ebiet wrote poems, but later he became a song writer. He was looking for a way to read a poem in a different way, without reciting on the stage. He chose and modified music into a poem lyric. He began to sing a song ballad that reflected the suffering of the people.

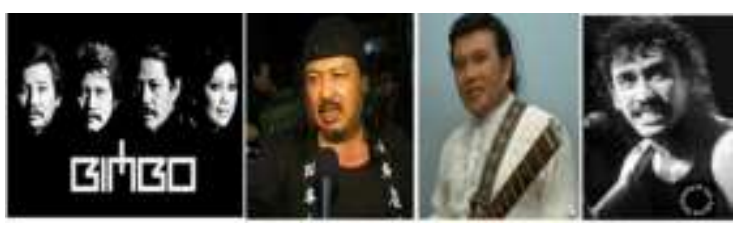

Figure 4. From right to left: Bimbo, Harry Rusli, Rhoma Irama, and Iwan Fals (source: timurangin.com)

In Bandung, there were four musicians who stood out because of their criticism. They were Bimbo, Harry Rusli (195I-2004), Rhoma Irama, and Iwan Fals. Bimbo was a group of musicians that often worked with the poets. The personnel of this group are all-related. They are Sam, Acil, Jaka, and lin Parlina. During a 40-year career, they've worked with a lot of poets such as Taufik Ismail 8, Ramadhan $\mathrm{KH}^{9}$, and Wing Kardjo ${ }^{10}$, but most of their songs were an adaptation of Taufik Ismail poems into popular songs. A music observer, Franky Raden, wrote that the most interesting phenomenon in Bimbo's songs is a process of transforming religious values through pop music.

Since the 1970's, Bimbo started to criticize the government. They wrote the satirical song Tante Soen (Auntie of Soen) to describe a situation when many official government wives used public facilities. The song Tante Soen was banned by the government in 1977. Because of this song, The Television of Republic Indonesia (TVRI), the only television channel at that time, banned Bimbo on the screen for several years. Bimbo also voiced what was happening in the world. One of the more famous songs is Reagen and Breznev to express their opinion when U.S. President Ronald Reagan visited Indonesia. They also wrote the song Antara Kabul dan Beirut (Between Kabul and Beirut) to protest the conflict in the Middle East. They further criticized the United Nations through the song The Elegy of United Nations. When Vietnam refugee came to Indonesia, they wrote The Ballad Hue Tran that explained what happened at that time.

Rhoma Irama is one of the senior critical Indonesian musicians. Based on various data sources, the number of people who bought his album and became spectators of his movies were about 15 million or $10 \%$ of Indonesia's population in 1984. Rhoma Irama also introduced dangdut music, which he called a Malay music. $\mathrm{He}$ is one of the most successful musicians who staged huge concerts. He not only appeared in Indonesia, but has performed in Kuala Lumpur, Singapore, and Brunei with the same number of viewers as when he performed in Indonesia.

On October 13, 1973, Rhoma proclaimed a slogan "Voice of Moslem". He wanted to be an agent of Malay musical innovator who combined elements of rock music and Malay music. He made an improvisation upon arrangements, poems, lyrics, costumes, and performances on stage. He also entered politics. In the early days of the New Order, he had become an important mascot of Partai Persatuan Pembangunan (The Uni Party of Development --PPP). After he was despised by the New Order government for refusing to join Golongan Karya (Golkar), Rhoma retreated from politics. Then, he became a Member of Parliament in 1993. In the 2004 elections Rhoma Irama also appear on stage of The Party of Justice ad Prosperous (Partai Keadilan Sejahtera -PKS) campaign."

Another critical musician was Harry Rusli (195I-2004). He is the grandson of one of the great literary authors from Minangkabau, Marah Rusli. During the 1970's, he was very productive 
to write lyrics that contained social criticism. Harry was recognized as an expert of satirical lyrics that were difficult to digest by the public.

In one of his songs, he referred to Indonesia as a peacock dog. On the one hand, Indonesia was beautiful like the charming peacock, but on the other hand, Indonesia was like an annoying dog. He wrote the song Ken Arok which referred to the president of the Soeharto. In 197I, Harry was arrested by the government because of his album cover Philosophy Gang contained pornographic aspects. He said that the album cover is a portrait of Indonesia's pathos. He criticized the commercialization of natural resources and agricultural products of Indonesia.

\section{Why Iwan Fals?}

In the midst of the many musicians who appeared in the 1980's, why should Iwan Fals be an icon of Indonesian critical music? In this article, I propose some arguments.

First, Iwan Fals is one of the most prolific musicians in Indonesia. A senior musician from Surabaya, Gombloh (1948 - 1988), who was also known to be very critical of the government, but only produced six albums during his whole music career. Another musician, Franky Sahilatua, produced around I 5 albums. Iwan Fals himself produced about 45 albums. Until now, he remains consistent to deliver musical albums that are made in accordance with the spirit of his time.

Bimbo was more productive than Iwan. Bimbo has released 50 albums. However, the lyrics of the Bimbo's songs are based on poems that were written by Taufik Ismail. If we see from the side of originality, Iwan Fals was actually more productive because he wrote almost all of his songs.

The only musicians who beat Iwan Fals is Rhoma Irama that has issued around 77 albums. ${ }^{2}$ But Rhoma Irama has a different audience with Iwan Fals. Most of Rhoma fans are coming from low class and those who live in the rural area, while Iwan Fals fans are mostly middle-class people who live in urban areas.
In the reformasi period, Rhoma Irama name was seldom mentioned by student activists because his critical songs were made in the 1980s. It may also be influenced by the fact that the Rhoma fans lived in rural areas while the reformasi movement was triggered and driven by the urban middle class who feel discomfort in government policy. We can compare the productivity data of critical musicians in the following table.

Table I. Critical Indonesian musicians

\begin{tabular}{|c|c|c|c|}
\hline City & Musician & Album & $\begin{array}{l}\text { Prominent } \\
\text { Song }\end{array}$ \\
\hline Jakarta & $\begin{array}{l}\text { Mogi } \\
\text { Darusman }\end{array}$ & $\begin{array}{l}6 \text { albums } \\
4 \text { singles }\end{array}$ & $\begin{array}{l}\text { Rayap-Rayap } \\
\text { (termites) } \\
\text { Puppet on } \\
\text { Life }\end{array}$ \\
\hline Surabaya & Gombloh & $\begin{array}{l}\text { I0 album } \\
\text { (Gombloh \& } \\
\text { The Lemon } \\
\text { Tree) } \\
5 \text { solo album }\end{array}$ & $\begin{array}{l}\text { Kebyar-Kebyar } \\
\text { Doa Seorang } \\
\text { Pelacur (A Pray } \\
\text { of A Prostitute) } \\
\text { Kilang-Kilang } \\
\text { (factories) } \\
\text { Nyanyian Anak } \\
\text { Seorang } \\
\text { Pencuri } \\
\text { (The Song of a } \\
\text { Thief's Son) }\end{array}$ \\
\hline Surabaya & Leo Kristi & $\begin{array}{l}4 \text { solo albums } \\
3 \text { festival } \\
\text { albums } \\
2 \text { albums with } \\
\text { C'Blues } \\
\text { I album with } \\
\text { Guruh } \\
\text { Soekarnoputra } \\
\text { I album with } \\
\text { Contrapunk }\end{array}$ & $\begin{array}{l}\text { Nyanyian Fajar } \\
\text { (The Song of } \\
\text { the Dawn) } \\
\text { Nyanyian } \\
\text { Tanah } \\
\text { Merdeka } \\
\text { (The Song of } \\
\text { the } \\
\text { Independent) }\end{array}$ \\
\hline Surabaya & $\begin{array}{l}\text { Franky } \\
\text { Sahilatua }\end{array}$ & $\begin{array}{l}\text { I0 solo album } \\
\text { I } 4 \text { duet } \\
\text { (Franky \& Jane) } \\
\text { I duet album } \\
\text { (Franky \& } \\
\text { Johnny) } \\
2 \text { album } \\
\text { (Franky, } \\
\text { Johnny \& Jane) }\end{array}$ & $\begin{array}{l}\text { Bis Kota (City } \\
\text { Bus) } \\
\text { Musim Bunga } \\
\text { (The Flower } \\
\text { Season) } \\
\text { Perjalanan } \\
\text { (The Journey) } \\
\text { Kepada Angin } \\
\text { dan Burung } \\
\text { (To the wind } \\
\text { and the Birds) }\end{array}$ \\
\hline Yogyakarta & $\begin{array}{l}\text { Ebiet G } \\
\text { Ade }\end{array}$ & 19 albums & $\begin{array}{l}\text { Berita kepada } \\
\text { Kawan (A } \\
\text { News for A } \\
\text { Friend) } \\
\text { Untuk Kita } \\
\text { Renungkan } \\
\text { (For Our } \\
\text { Contemplation) }\end{array}$ \\
\hline Bandung & Bimbo & $5 \mathrm{I}$ albums & $\begin{array}{l}\text { Tante Soen } \\
\text { (Auntie Soen) } \\
\text { Abang Becak }\end{array}$ \\
\hline
\end{tabular}




\begin{tabular}{|c|c|c|c|}
\hline & & & $\begin{array}{l}\text { Kampanye } \\
\text { Pemilu } \\
\text { (Election's } \\
\text { Campaign) } \\
\text { Elegi buat PBB } \\
\text { (Elegy for Uited } \\
\text { Nations) }\end{array}$ \\
\hline Bandung & $\begin{array}{l}\text { Harry } \\
\text { Rusli }\end{array}$ & $\begin{array}{l}23 \text { solo albums } \\
8 \text { collaboration } \\
\text { albums }\end{array}$ & $\begin{array}{l}\text { Fraksi Pencuri } \\
\text { (A Group of } \\
\text { Thieves) } \\
\text { Ken Arok } \\
\text { Merak } \\
\text { (Peacock) }\end{array}$ \\
\hline Bandung & $\begin{array}{l}\text { Rhoma } \\
\text { Irama }\end{array}$ & $\begin{array}{l}23 \text { album (with } \\
\text { Soneta group) } \\
27 \text { soundtrack } \\
\text { albums } \\
27 \text { solo albums } \\
25 \text { films }\end{array}$ & \\
\hline
\end{tabular}

Bandung Iwan Fals

Second, Iwan Fals has many fanatical fans who spread his ideas across Indonesia and the world. The fans come from different social backgrounds, ranging from the upper class, the middle class, down to the 'grassroots'. Many of them see Iwan Fals as a God. They display Iwan Fals' poster pictures everywhere. The imagery of Iwan Fals is often illustrated in their t-shirts. Also, many of his fans made a tattoo of Iwan Fals as a symbol of loyalty.

In reality, he also has a charisma that makes everyone willing to attend his show. This charisma is a rare power that is not owned by other singers and musicians. It is not surprising then to hear that Iwan Fals' concert in 1990 became the biggest concert with the largest audience in Indonesia. ${ }^{13} \mathrm{He}$ made a new history of pop music concerts that were attended by thousands of spectators.

Compared with other musicians, Iwan Fals is one of the only singers who formed a massive organization for all his fans called Orang Indonesia (the Indonesian people -- Ol). While other singers also form fans club like Leo Kristi and Harry Rusli who have many fans, but the number is much less. Iwan Fals' fans organization is different compared to all others. He manages the organization with the goal to empower its members' economic background and develop a sense of community. This mission explains why, on August 2, 1999, he invited thousands of its members to come to his home in Leuwinanggung, Bogor, to talk about this organization.

A huge number of fans that have various backgrounds came to his house. They agreed to make the $\mathrm{Ol}$ into a mass organization. They planned a national gathering which was attended by thousands of fans. They formed the organization in all cities throughout Indonesia with an estimated number of members exceeding 500,000 people. The latest information I have received is the number of $\mathrm{OI}$ in Indonesia has reached over a million people. This number is a fantastic amount for musician fans in Indonesia. However, this number is not totally true. According to a study by a student of the University of Indonesia in 2002, Iwan has 46 million fans. In comparison, Susilo Bambang Yudhoyono (SBY) garnered slightly over 60 million votes in the 2004 elections to become the country's first democratically elected president, while the incumbent Megawati Sukarnoputri at that time collected only slightly over 40 million votes in the runoff election. ${ }^{14}$

Fourth, Iwan Fals is one of the few musicians who has a strong network with prodemocracy activists. From the political perspective, Franky Sahilatua choose the same path as Iwan. In the reform period, both of them wrote songs about the violence which was created by the military toward members of the Indonesian Democratic Party (PDI) that was led by Megawati. Different than Sahilatua, Iwan was more influential to the masses.

On the eve of reformasi, Iwan Fals joined with the Kantata Takwa, a progressive network of the regime's challengers, along with the critical poet, WS Rendra. According to the journalist, Andreas Harsono, in the 1990s, Iwan Fals often came to Salatiga to meet the prominent activist and sociologist, Arief Budiman ${ }^{15}$. He learned how to understand political issues from Arief Budiman. He also read and was influenced by the book, Catatan Seorang Demonstran (Notes of A Demonstrator), that 
was written by Soe Hok Gie, the younger brother of Arief Budiman.

Iwan Fals also often held discussions at his home in Leuwinanggung, Bogor. He invited speakers such as Budiman Sudjatmiko'6, Sri Bintang Pamungkas ${ }^{17}$, Khofifah Indar Parawansa ${ }^{18}$, Franz Magnis Suseno ${ }^{19}$, and the former Minister of Youth and Sports, Adhyaksa Dault. The discussion topics were varied, such as religion, love, politics, piracies, violence against women, AIDS disease, the fuel price hike, corruption, strikes, labor issues, and the national debt. Through this discussion, he tried to get inspiration and also built a network with these critical figures in order to learn from them.

Fifth, Iwan Fals's influence is not only felt in Indonesia but also in other countries. Mandal (2003) noted that Iwan Fals influenced many Malaysian artists in their anti-establishment criticisms. One of them is the famous Malaysian cartoonist, Zunar ${ }^{20}$. Similar to Iwan Fals' lyrics, Zunar creates political cartoons to criticize politics in Malaysia. Zunar has also written about the collaboration of Iwan Fals with several artists as an effective force to overthrow the regime. Zunar gave a strong conclusion, if artists in Malaysia might be able to collaborate fruitfully to do the same thing. ${ }^{21}$ No wonder when Iwans' name was mentioned as the Asian hero by Time Magazine.

Sixth, Iwan Fals songs could explain many socio-political contexts of the New Order. The songs recorded the events in the New Order period and also described human interactions that existed at that time. Prostitutes, the jobless, thugs, underpaid teachers, newspaper vendors, the homeless and thieves, all of them have their own special place in Iwan's lyrics.

Some attribute his close relations with the marginalized people to his experience as a busker or street bard in Jakarta and Bandung from the age of 13. Even after producing four albums from 1979 to 1987, including Sarjana Muda and Sugali, Iwan Fals often still performed on the streets, especially in the Blok $M$ area in South Jakarta.

I am interested to see the relationship between the music and lyrics of Iwan Fals that relate to social context. Maybe, the lyrics of Iwan Fals' songs can help us to better understand the situation at the end of the New Order. Perhaps, his songs provide more insights into recognizing the deepening social history of the New Order.

In addition to the above mentioned questions, I also want to highlight two controversies concerning Iwan Fals. First is his family background. This history is a very interesting fact to be explored. Though his songs often promoted grassroots phenomenon, Iwan Fals actually came from a middle class family. His father was a soldier with the rank of colonel. If Iwan Fals comes from a military family, why would he make some lyrics criticizing the military?

Second is Iwan Fals' close connection with many businessmen. As part of the upper classes, who made friends with entrepreneurs, can we say that he was a propaganda tool of the entrepreneurs and the middle class to topple down Suharto? Given the circumstances, can we explain the reformasi as an expression of the middle class who actually wanted social change?

\section{A Short Biography}

His full name is Virgiawan Listianto. He was born in Jakarta, September 3th, 196I as the fifth of nine children. His father's name is Harsoyo who came from Blitar, East Java. His father was a soldier with the rank of colonel. His mother was Suudiyah Lies, originally from Solo, Central Java. His mother is a woman of Arab descent.

Information about his father is very limited. It seems that he very rarely talks about his father. He has a lot to discuss about his mother; he even created a song about her. But he never wrote a song about his father. In one interview, he said that he grew up in a militarystyle discipline. As a boy, he dreamed of becoming a soldier. He failed to accomplish his 
dream later on because he was far more interested in becoming a musician.

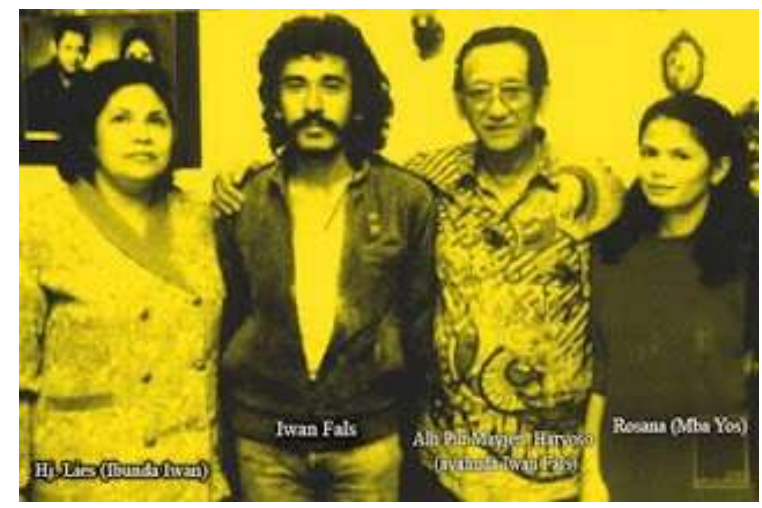

Figure 5 From left to right: Hj Lies (Iwan's mother). Iwan Fals, Harsoyo (Iwan's father), and Yos (Iwan's wife) (source: timur-angin.com)

In an interview with Tempo, he said that in his childhood, he was very proud to be a soldier's child. When one day he fought with the neighboring children, he took his father's AK-47 to scare the neighbours. ${ }^{22}$ About his parents, he said:

My father was a soldier. But he was not a fierce army man. In fact, my mother was fiercer than my dad. Well, I hope others soldiers are like him too. ${ }^{23}$

As usual in the soldier families, discipline was often enforced in the home. Iwan Fals said that his parents taught a religious discipline. For example, he should not be playing music while people were praying. If he keeps playing music, then his father will become angry. He explained:

When I was a boy, I got a piano. Sometimes I played in the house, so it sounded noisy. If it was time to pray, my father would get angry. My parents were strict in religion. I've became a winner in azan competition among elementary student in Jakarta. ${ }^{24}$
This is an interesting fact to be explored. Some critical musicians also were from military families. Some of them are Rhoma Irama and Yapi Tambayong (Remy Silado). Interestingly, despite being born into a military family, he often criticized the military.

My father is a soldier. I was taught to be disciplined. I am a black belt in karate. If you do not discipline, you could not be a black belt. My parents have always been supportive. They said as long what I believe is true, do it. My mother regrets for one thing. Why I did not become an engineer? After she saw my performance, she became endeared to me. 25

In several interviews, he refused to explain his father's high position in the military. Maybe it is because at the age of II years, he moved to Bandung where two of his sisters lived. He studied at junior high school (SMP) 5 Bandung. Since he didn't want to live with his sisters, he lived alone in a dormitory. Apparently, he wanted to be more independent. Maybe, he felt more freedom without his family.

Subsequently, he moved to Jakarta and then later became a street singer. He refused to stay at home because his family was too strict toward him. His life history is similar to the story of Ali Topan in the novel of Ali Topan Anak Jalanan (Ali Topan A Street Child) that was written by Teguh Esha. Similar to Ali Topan, Iwan Hals choose to live outside his home, and became a street busker. There is no clear answer why he became a musician. He explained his choice in one of his songs. ${ }^{26}$

$\begin{array}{cc}\text { Aku pergi } & \text { I run away } \\ \text { meninggalkan coreng } & \text { leaving a black stain } \\ \text { hitam } & \text { in my father's face } \\ \text { di muka bapak } & \text { that shames } \\ \text { yang membuat malu } & \text { my family } \\ \text { keluargaku } & \end{array}$




\author{
Kuingin kembali \\ Mungkinkah mereka \\ mau terima \\ Rinduku
}

$$
\begin{aligned}
& \text { I want to go back } \\
& \text { Could they be } \\
& \text { willing to accept my } \\
& \text { longing for them? }
\end{aligned}
$$

His spirit of resistance began to emerge when studying in junior high school. At that time, he wrote his first song called "Aku dan Sekolahku" (Me and My School). The lyrics talk about the actions of a teacher toward the students. Inspiration came when his female classmate came to school wearing lipstick. The teacher was angry and sent her to the bathroom to get water that was put into the bucket, and then brought to the classroom. In class, the angry teacher wiped her lipstick. The female student was embarrassed and started crying. Iwan protested through his song.

Then, he returned to Jakarta. After that, he followed his brother to Jeddah, Saudi Arabia, for eight months. His parents wanted him to have more focus in school in Jeddah. He stayed there for more than eight months. He described this part of his life as the difficult phase because almost every day he missed his homeland. The only consolation for him was the guitar that he brought from Indonesia. He always played two songs; "Sepasang Mata Bola" (A Pair of Ball Eye) and "Waiya." Finally he returned to Indonesia. On the way home, he met a stewardess who taught him about Bob Dylan's song called Blowing in the Wind.

Returned from Jeddah, he lived in Jakarta. Soon after, he went to Yogyakarta, and after that he returned to Bandung. He also went back to school and spent time as a street musician. At that time, the young generation in Bandung liked the Rolling Stone's music. Iwan Fals wanted to be different with his friends, so he started to play his own song. In Bandung, he grew up as a street busker. He said: "I was singing everywhere. The songs that I brought were new songs that told the actual problems of our society."

In Bandung, he began recording in $8 \mathrm{EH}$ Radio that was owned by students of the Institute of Technology Bandung (ITB).
Unfortunately, the radio was shut down by the New Order government. His experience on the streets made him understand about the actual issues in the community. He also learned to find songs that were compatible with the conditions and acceptable to the community. Then he moved to Jakarta to start his new life away from home as a free man.

With respect to Iwan's experience, there are two assumptions that can be mentioned here. First, as noted by Shiraishi (1997), what was missing in the New Order family is the sense of belonging. Children, both young and old, were rarely found in their houses during the day time when school was over. They freely moved around the neighborhood alleys and the narrow spaces between houses. ${ }^{27}$

Second, Iwan Fals grew up in a middleclass family who enjoyed many facilities and luxuries in the New Order. But it seems that he choose to leave his home, and then express himself through his music. In the New Order period, its rapid development program successfully created a layer of middle-class. Later on, the middle class became a group that was politically educated about their rights. This group held a critical awareness and understanding of the complex social reality, which explains why they began to criticize the government.

After he become more popular with his protest songs, Iwan Fals formed a new group, Swami, which also included a prominent vocalist Sawung Jabo. After the Swami Band, Iwan Fals and Jabo joined in Kantata Takwa with W. S. Rendra (1935 - 2009) and Setiawan Djody. They were from the high-class background. Jabo graduated from one of the prominent universities in Australia. $\mathrm{He}$ is also married to Suzan Piper, an Australian girl.

Rendra was born in Solo, Central Java. He is a poet who is often dubbed as the 'Peacock'. He founded the Bengkel Theater in Yogyakarta in 1967. When the theater group became in disarray because of political pressure, then he 
founded the Bengkel Theater in Depok, October 1985.

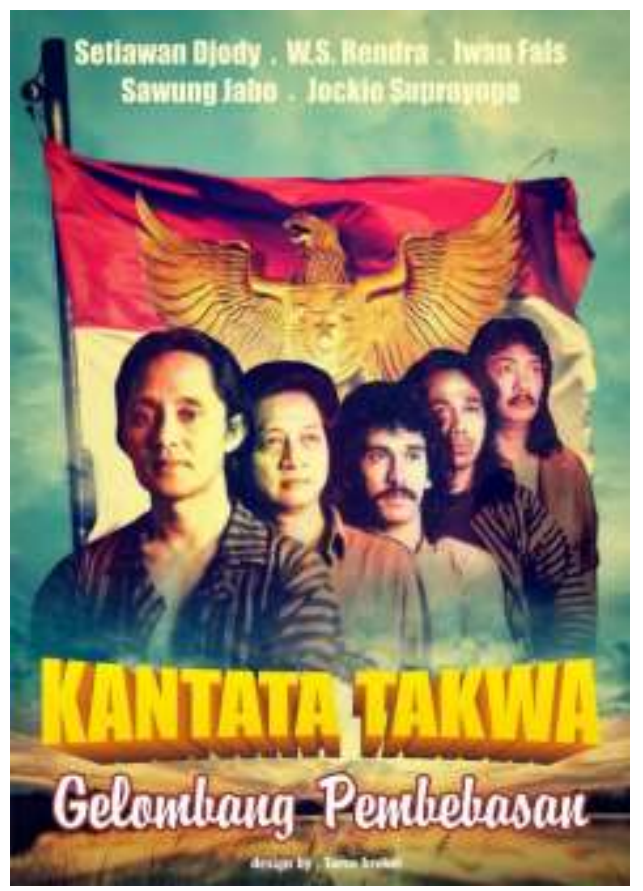

Figure 6. Kantata Takwa (source: timur-angin.com)

He was active in writing short stories and essays in various magazines since he studied in a college. Rendra was a poet with an international reputation. He also actively participated in festivals abroad, including the Rotterdam International Poetry Festival ( 197 I \& 1979), The International Poetry Festival Valmiki, New Delhi (1985), Berliner Horizonte Festival, Berlin (1985), The First New York Festival of the Arts (1988), Spoleto Festival, Melbourne, Vagarth World Poetry Festival, Bhopal (1989), World Poetry Festival, Kuala Lumpur (1992), and Tokyo Festival (1995).

Setiawan Djody (born March 13, 1949; Solo, Central Java, Indonesia) is an Indonesian businessman and guitarist. He was a Wharton School graduate in 1974 and got the S-2 Philosophy from the University of California. He is the Chairman of Setdco group in Indonesia. Setdco was named after his own name.
$\mathrm{He}$ is also a musician, being listed by Rolling Stone as one of Asia's top guitarists. The majority of Setdco investments are in the areas of oil business, the media and agro-industry; including telecommunications. $\mathrm{He}$ is listed in the I 50 Richest Indonesians by the Forbes magazine 2007. He is also active in the business of shipping and has several shipping companies.

Djody is a businessman who is considered close to the Soeharto family. In 1976, he started an oil and gas business with Sigit Harjojudanto, the first son of President Soeharto. Through Sigit, Djody got a contract with National Oil Mining (Pertamina) to transport oil to other countries. He also owns the tanker business. About his relationship with the Suharto family, Djody said:

From the beginning of my business, I was close to Sigit. We have a partnership. In the 1980's, we had a conflict of interest. But we became close as a friend. Sometime I have a different perspective with him. Sometime we talked about the weakness of the New Order regime. ${ }^{28}$

While many Iwan's fans accused him as being part of the family of Cendana ${ }^{29}$, Djody rejected this premise:

If the title is my closeness to Cendana's family, I will not be angry. But when they said that I am one of the cronies of New Order, I will not accept. I have a painful experience in the New Order era. I can't grow. They treated me like a bonsai. For a year I was not able to go abroad. I was accused of influencing Suharto's children. If I am one of Suharto cronies, why did I work with Iwan Fals? ... I knew Mr. and Mrs. Tien Soeharto. I respected them as parents. They acted as a ksatriya of Java. We worship Resi Bhisma, then going to the war. I'm not Sengkuni. I'm not a Durno the traitor. ${ }^{30}$

After he stopped his business with Sigit, he collaborated with Hutomo Mandala Putra, 
Suharto's youngest son, to produce Lamborghini cars in Indonesia. These facts show the closeness of Djody to Cendana's family. What's Iwan Fals' opinion about Djody?

I do not know. I have no idea about political attitudes. Djody is still my cousin from my father's family. At first, I did not know if he is my family. When we established Kantata Takwa, I knew this information. I have a male cousin who often visits Djody's home. Apparently we are still brothers. My father knows Djody's father. I do not know if Djody had a political agenda.

Iwan Fals' statement is interesting to be traced. If Djody is one of Iwan's family, then it is very reasonable if $\mathrm{Djody}$ funded the concert of Iwan Fals everywhere. Perhaps, Djody also protected Iwan from the military in the era of New Order. The question does arise. Did Iwan Fals worry that Djodi tried to control him as a critical musician?

Maybe. He always said, "Before people say anything about Soeharto, I was singing the song Bongkar. I also sang Bento." Mas Jody always quote it right? Is it a hoax? I do not know. Maybe that's a lie. But Djody has the right to make a friend with me. The song Bento and Bongkar is not about Soeharto. It is about the persecution. I could be Bento, Djody could be Bento. Just because it was published by the media, many people say it is associated with Suharto. There are many abbreviation of Bento. Some say Benteng Soeharto (The Fortress of Soeharto), Benci Soeharto (the Hateness of Soeharto), and Benny Soeharto. That's what make it a good selling. I was so proud. It was written in newspaper. Hahaha...

Although Iwan Fals did not admit to Djody's political influence, he was influenced by Djody. A few years before the reform, Iwan along with Djody and the personnel of Kantata
Takwa performed in over 100 cities. They raised people awareness about the fragile of governance regime. They strengthened their relationships with pro-democracy activists to overthrow Soeharto, an important figure to Djody.

From these facts, we can conclude that Iwan Fals and his group were part of the middle class who were involved with the New Order government. They joined with other middleclass alliances to overthrow the Suharto regime.

There are several studies about the middle class during the New Order. One of them is the study of Robinson (1993) who said that the middle class was dependent on state protection. Members of this class were always able to adjust themselves and were closer to the center of political power to get the development cake. When the political winds moved to the side of liberalism, they asked the government to protect their vulnerable resources.

They became spokesmen for the military policy in a centralized political system around the figurehead leader, and the political economy that relied on cheap labor and massive exploitation of natural resources. With this political character, as written by Robison, the picture of the middle-class in the New Order was difficult to be better described. They were a class depoliticized, materialistic, and their ideas were driven by authoritarian ideas more than democratic ideas.

The new middle class began to show an increasing insubordination, when the $\mathrm{New}$ Order regime had difficulty in fulfilling their interests. Political calculations showed that being behind Soeharto would not be beneficial for the future.

These political predictions come true with the exodus wave of cabinet members led by Ginandjar Kartasasmita in 1998. The middle class finally became disobedient when many companies became bankrupt in the economic crisis period before 1998. Together with the radicalized student movement, the middle class 
members joined to start a rebellion and a demonstration until Soeharto stepped down.

If the journey of Iwan Fals and his music group is a representation of the middle class, a question arises. What life phases affected the music of Iwan Fals? Why did he criticize the military in his songs? What were the real social situations that he wanted to address through his outspoken music?

\section{Historical Context}

In sociology, there are many ways to describe the relationship between research subjects and social context. Some scientists state that the relationship between the individual and the context is the relationship between agency and social structure. By applying this concept to studying Iwan Fals' thought and way of life, we can better understand how the historical conditions influenced Iwan Fals appeared in his songs.

Most of Iwan Fals's albums were released in the 1980s and 1990s. In the early period of his career, Iwan played folk songs. The character of each of his songs plus the lyrics made his style often associated with Bob Dylan. Social criticism appeared in 16 albums that were produced by Iwan Fals in this period. These albums are: Perjalanan (The Journey) in 1980, 3 Bulan (Three months) in 1981, Sarjana Muda (The Young Scholar) in 1981, Opini (Opinion) in 1982, Sumbang (Disordant) in 1983, Barang Antik (Antique) in 1984, Sugali (1984), KPJ (1985), Aku Sayang Kamu (I Love U) in 1985, Ethiopia (1986), Lancar (Smooth) in 1987, Wakil Rakyat (People's Representative) in 1987, 1910 (1988), Antara Aku Kau dan bekas pacarmu (Between Me, You, and your Former Boyfriend) in 1988, Mata Dewa (The God's Eye) in 1989, and Swami (1989).

From these albums, there appears a variety of themes such as social deviance, authoritarian rule and corruption, development and social change, inequality and poverty, natural disasters and humanitarianism.

Iwan Fals criticized the New Order government that made a statement that Indonesia's economic progress was the goal of

development. One of the songs that represents this theme is Sarjana Muda (Young Bachelor) which was released in 1981. This song illustrated the difficulty of finding employment for young scholars. One of the lyrics said:

$$
\begin{gathered}
\text { Engkau sarjana muda, } \\
\text { resah mencari kerja, } \\
\text { mengandalkan } \\
\text { ijazahmu }
\end{gathered}
$$

Empat tahun lamanya
Bergelut dengan buku
Sia-sia semuanya
Setengah putus asa
Dia berucap,
"maaf ibu"

$$
\begin{aligned}
& \text { You're young } \\
& \text { bachelor } \\
& \text { anxious to find a job } \\
& \text { With your degree }
\end{aligned}
$$

Four years

Struggle with books

Everything is useless

When half despair

He say,

"sorry mom".

This song describes the social situation in which a college graduate faced difficulties to find a job. In 1980-1989, the economic situation was stable enough to run economic programs. In the early part of $\mathrm{New}$ Order, the Indonesian government launched Law Number I of 1967 about foreign investment, then continued with Law No. 12 of 1970 which opened the flood gate for foreign investment.

The initial process of economic development that relied on foreign capital started from the early 1970's. Critique of economic injustice and poverty also started than because economic development was only enjoyed by a particular group that was closed to the government. In the early 1980's, Iwan Fals felt the discrepancy when many people were still poor. He wrote a song about a teacher named Oemar Bakrie who, even in this technological age, still had to ride an old bicycle, while his low wages consistently dropped every month.

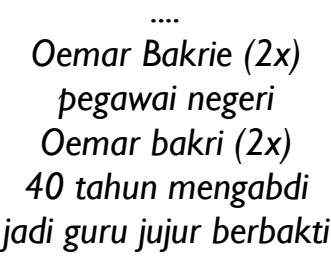

Oemar Bakri (2x) a civil servant

Oemar Bakri (2x) 40th served 


\author{
memang makan hati \\ Oemar Bakri (2x) \\ banyak ciptakan \\ menteri \\ Oemar Bakri $(2 x)$ \\ professor, doctor, \\ insinyur pun jadi \\ tapi mengapa gaji guru \\ seperti dikebiri \\ as a teacher honestly \\ serve \\ is eating liver \\ Oemar Bakri (2x) \\ create many \\ ministers \\ Oemar Bakri (2x) \\ creates professors, \\ doctors, and \\ engineers \\ but why the wage of \\ Oemar Bakri \\ seems to be \\ corrupted
}

When Iwan Fals asked, "Why the wage of Oemar Bakri seems to be corrupted? He was making a subtle satire about corruption that was initiated by the government. Why did Iwan Fals create this song? When I asked him this question, he answered:

Each song just came to me. A song is a calling. I used to be a student in a school, so I could tell about my teacher. Many people asked me whether Oemar Bakrie is real character or not. Initially, I would like to give the name Abdul Gani in my song. Because I have friend name Abdul Gani, then I changed to Oemar Bakri. Hahaha .. What was the message? When I wrote the song, I did not know about the message. I just wrote. After the song was performed, I tried to make analyzes. Maybe there was a story of simplicity, innocence, or something else. ${ }^{31}$

Iwan Fals also talked about his feelings as a parent when his son, Galang Rambu Anarki, was born. He said in his song:

\section{Galang Rambu Anarki anakku \\ lahir awal januari menjelang pemilu \\ Galang Rambu \\ Anarki dengarlah}

\author{
terompet tahun baru \\ menyambutmu \\ galang rambu anarki \\ ingatlah \\ tangisan pertamamu \\ ditandai bbm \\ membumbung tinggi \\ (melambung) \\ maafkan kedua \\ orangtuamu \\ kalau tak mampu beli \\ susu \\ bbm naik tinggi \\ susu tak terbeli orang \\ pintar tarik subsidi \\ mungkin bayi kurang \\ gizi (anak kami)
the new year's you \\ trumpet welcome \\ Galang Rambu \\ Rambu Anarki, \\ remember \\ Your first cries were \\ marked \\ by oil price soaring \\ forgive your parents \\ if we cannot buy a \\ milk \\ oil price soar \\ the milk was \\ unbuyable \\ smart people \\ remove subsidies \\ probably my infant \\ malnourished
}

The next theme is a criticism of the authoritarian and corrupt government. Iwan Fals wrote about 13 songs that criticized the government' repression of the people. In his songs, he also considered the government as a corrupt government who did not care to its people. One of the songs that is quite popular is "Tikus-Tikus Kantor" (Office Rats) in 1986 that described the corruption in the workings of the government.

In those years, the repression of the New Order was very strong but not totalitarian. As the president, General Suharto mixed military and civilian control and permitted some limited resistance but kept the masses "fluctuating" - or politically "neutral" and intentionally omitted the Marxists. These policies created stability and mediated the appearance of an educated urban middle class, but at the expense of some systematic tyrannies of weaker social forces as well as the imposition of a highly manipulated political structure.

In the 1980's, there were many tragedies that showed the repression of the people. They included: Tanjung Priok, when the government applied a single principle of Pancasila, mysterious shooting or sniper (petrus), and also Lampung 
tragedy. In every tragedy, there were many civilians killed.

Iwan Fals also suffered serious tragedy when his performance was banned by the government. The critical lyrics of his songs soon attracted even more attention, including a twelve-day interrogation by local police on Riau Island in 1984, after he helped a student fundraising effort. Iwan told the story:

At that time I was interrogated by police officers for 14 days in Pekanbaru. They accused that I was insulting the president through the song Rice Democracy and Mbak Tini. This song is a story about a coffee shop waitress and her husband named Suhardi. But on stage, I changed Suhardi into Suharto. The song Mbak Tini is a story about a driver and a maid cafe. The driver was a former thief. They want to marry. But the driver became a thief again. The woman returned to be a prostitute. At that time I was young. Maybe I was influenced by the Suharto because I always heard his name on television. At that time I was confused. I even cried. 32

As Fals explained, the song Mbak Tini is about the struggle of a truck driver laid off by the government. His song reflected sympathy and criticisms against the human cost of $\mathrm{New}$ Order's socio-economic fluctuations, such as low paid teachers, shoeshine boys, desperate prostitutes and unemployed university graduates.

During the 1980s, a narrow multiparty parliamentary scheme developed, but Golkar, a functional coalition of groups allied to the military and bureaucracy, dominated stateengineered elections and the whole country's political agenda in what has been called a 'hegemonic party system.' The electoral campaigns, routinely but alluringly labeled 'Festival of Democracy', were ritualistic and orderly in its rhetoric, with large numbers of security police. Behind the scenes, the military remained the main arbiter of power.
In one of his songs, Iwan Fals criticized the insensitivity of members of the House of Representatives. He said:

\begin{tabular}{|c|c|}
\hline $\begin{array}{c}\text { Wakil rakyat bukan } \\
\text { kumpulan orang } \\
\text { hebat } \\
\text { bukan kumpulan } \\
\text { teman-teman dekat } \\
\text { apalagi sanak famili }\end{array}$ & $\begin{array}{l}\text { People's } \\
\text { Representative is not } \\
\text { a group of greatman } \\
\text { not a group of close } \\
\text { friends } \\
\text { moreover relatives }\end{array}$ \\
\hline $\begin{array}{l}\text { Di hati dan lidahmu } \\
\text { kami berharap } \\
\text { suara kami tolong } \\
\text { dnegar lalu } \\
\text { sampaikan } \\
\text { Kami tak sudi } \\
\text { memilih para juara } \\
\text { juara diam, juara } \\
\text { malas, juara hahaha } \\
\text { wakil rakyat } \\
\text { seharusnya merakyat } \\
\text { jangan tidur waktu } \\
\text { sidang soal rakyat } \\
\text { wakil rakyat bukan } \\
\text { paduan suara } \\
\text { hanya tahunya diam } \\
\text { lalu setuju }\end{array}$ & $\begin{array}{l}\text { In your heart and } \\
\text { tongue, } \\
\text { we put our hope } \\
\text { please listen our } \\
\text { voice and speak } \\
\text { We're not choosing } \\
\text { the winner } \\
\text { The winner of silenty, } \\
\text { the winner of } \\
\text { laziness, the winner } \\
\text { of hahaha } \\
\text { People's } \\
\text { representative should } \\
\text { be humble } \\
\text { do not sleep when } \\
\text { attending session } \\
\text { about people } \\
\text { People's } \\
\text { representative is not } \\
\text { a choir } \\
\text { who only knows } \\
\text { about being silent and } \\
\text { agreeing }\end{array}$ \\
\hline
\end{tabular}

Although the New Order had great achievements in the economy, the freedom of expression was not guaranteed. The government relied on a strong centralization of power in the hands of President Soeharto and his followers. Political freedom was suppressed by physical violence, detention and bans of certain publications or actions. Political power of the New Order was an authoritarian bureaucracy character that marked the dominance of the role of the State in all areas 
and ultimately the suppression of all opposing political power.

Through his music, the next theme that Fals wanted to address was a critique of development and social change. When the development phrase was introduced, many people became the victims. The government prioritized modern industrialization more than agricultural development. In response, Iwan Fals wrote a song "Surat dari Paman di Desa" (Letters from Uncle in the Village) that was published in 1981. This song describes how the village people were evicted for the sake of investors who wanted to build factories.

$\mathrm{He}$ also wrote the song Bento that was based on the fact that many entrepreneurs built real estates and bought villager's land. Many mass media said that Bento was an abbreviation of Benci Suharto (Hate Soeharto). Others said Benci Tommy Suharto (Hate Tommy Soeharto) or Benny Soeharto.

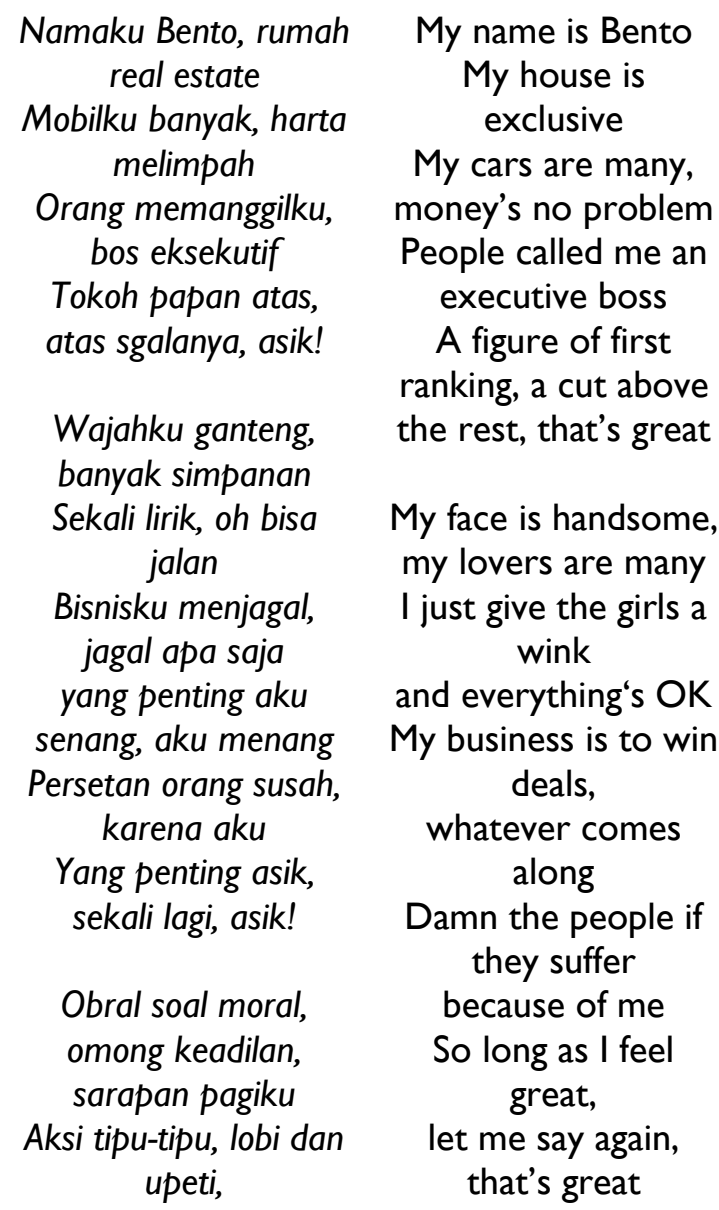

$\begin{array}{cc}\begin{array}{c}\text { woo jagonya } \\ \text { Maling kelas teri, }\end{array} & \begin{array}{c}\text { Summons of } \\ \text { morality, talk of } \\ \text { justice }\end{array} \\ \begin{array}{c}\text { bandit kelas coro, itu } \\ \text { kantong sampah } \\ \text { Siapa yang mau } \\ \text { berguru, }\end{array} & \begin{array}{c}\text { That's my breakfast } \\ \text { menu }\end{array} \\ \begin{array}{c}\text { Scheming, lobbying, } \\ \text { and business graft } \\ \text { lang padaku, sebut } \\ \text { Bento bento bento.. } \\ \text { asik.. }\end{array} & \begin{array}{c}\text { Petty the champ } \\ \text { small-time hoods } \\ \text { They're just rubbish } \\ \text { to me }\end{array} \\ & \begin{array}{c}\text { If you want to learn, } \\ \text { just come to me }\end{array} \\ & \text { Say my name three } \\ & \text { times, } \\ & \text { Bento, Bento, Bento } \\ & \text { That's great }\end{array}$

This song is considered by many to be a criticism of Soeharto. This song was made when the government was monitoring all media content. The authorities, concerned with limiting the potential for disorder, considerably restricted the airing of opposing viewpoints and closely monitored the mass media, most of whom practiced self-censorship or came under formal or informal government surveillances. The government at that time viewed the media largely as an unofficial 'bulletin' or 'conveyor belt' for government information, and most editors promoted close relationships with members of the ruling elite only to retain their jobs.

By the time when Bento was launched, the mass media speculated that the song was going to critic Suharto. In fact, Iwan said that he want to denounce the suppression.

Many people think that this song was about Soeharto. Do I really hate him? No. I was tired because his period was too long. I do not understand politics. I just wanted a new atmosphere. Maybe the press exaggerated my opinion. At that time, there were a phenomenon of real estate and new families who live in the housing. And also we could find corruption in everywhere. Why l use the 
name of Bento? I thought no one called Bento. I could use the name Andi, Budi, or any other name. Although there was a football player from East Timor name Bento, this name became abbreviations of Benci Soeharto (hate of Sueharto), Benci Tommy (Hate Tommy), or a Benny Suharto. 33

The song that is also most remembered like Bento is Bongkar (Demolition) which depicted the suffering of citizens of Kedungombo village at Central Java.

Kalau cinta sudah
dibuang
Jangan harap keadilan
akan datang
Kesedihan hanya
tontonan
Bagi mereka yang
diperkuda jabatan
Oh oh ya oh ya oh ya
bongkar
Oh oh ya oh ya oh ya
bongkar
Sabar sabar sabar dan
tunggu
Itu jawaban yang kami
terima
Ternyata kita harus ke
jalan
Robohkan setan yang
berdiri mengangkang
Penindasan serta
kesewenang wenangan
Banyak lagi teramat
banyak untuk
disebutkan
Hoi hentikan hentikan
jangan diteruskan
Kami muak dengan
ketidakpastian dan
keserakahan
Di jalanan kami
sandarkan cita cita

\section{Oppression and} injustice

Are too numerous to mention stop it, stop it, do not continue

We are fed up with the uncertainty and greed

In the street, we put our dream
Sebab dirumah tak ada lagi yang bisa dipercaya. Orang tua pandanglah kami sebagai manusia Kami bertanya tolong kau jawab dengan cinta
Because in home, there is no one to be trusted

Old man, see us as human being We ask you. Please answer with love

The song "Bongkar" was written when the Kedungombo village was to be forcefully sunk by the government for dam construction project. Iwan Fals joined with many non-governmental organizations to protest the project that was funded by the World Bank. The protest was ignored by the government. Iwan Fals sang his protest song in a music concert with Rendra and his Bengkel Theater group spectacularly attracted 120,000 to 200,000 to the Gelora Bung Karno Stadium in 1990, marking it as the largest concert in the nation's history.

The song Bongkar was created when I lived in Condet, Jakarta, in 1989. What was the message? There was a story about Kedungombo. I was a little bit upset with the government. Kedungombo was a village that was submerged by government to make a dam. There were also the Kacapiring case and Way Jepara in Lampung where many people became victims. At that time I created this song with Jabo. Finally, we chose the word "oppression and tyranny." 34

Finally, Iwan Fals' songs demand democratization and human rights, condemn corrupt power holders in government and business, sympathize with the poor, criticize the hypocrisy of the media and the blindness of parents.

Iwan particularly has received wide admiration among the urban youth, including both from the kampungan (villages) and university circles. Everyday dozens of youth visit the singer's home, imitating his fashion brand of blue jeans, long hair, and scarfs. Indeed, in 1990, 
a magazine was banned for a survey that listed Iwan (and Soeharto) more popular than the Prophet Muhammad, who was the eleventh and as a result, devout Muslims were outraged.

Since 1990, he is no longer creating the song. He joined with the pro-democracy movement to awaken many people. For several years, he continued to sing protest songs, until finally Presiden Soeharto resigned.

\section{CONCLUSION}

After reading and studying the life history of Iwan Fals, there are several conclusions that can be learned.

First, the Iwan Fals' songs, especially those were written during the New Order, represent the social reality of that era. The themes that were written by Iwan are protest issues such as injustice, oppression, and critical thought to the government. These topics describe the social conditions of the time.

Secondly, Iwan Fals' songs are the forms of expression of the urban middle class who want to change the regime. The background of Iwan Fals and other musicians are coming from middle class, which got benefit in the era of the New Order. Then, they felt dissatisfied to the government policy at the end of 1990s.

Third, Iwan Fals' experience can be a gate for us to understand the social dynamics and how the people respond to it. For Iwan Fals, pop music is a tool of resistance to authority. Although he did not admit it, but his songs had a power to raise public awareness about the problems that were caused by the regime.

Fourth, the lyrics of Iwan Fals' song doesn't provide detailed information about the history or what happened in the past, but they can help us to understand how the subjects understand the history, and how the subjects articulate them into their daily life.

\section{Discography}

Album

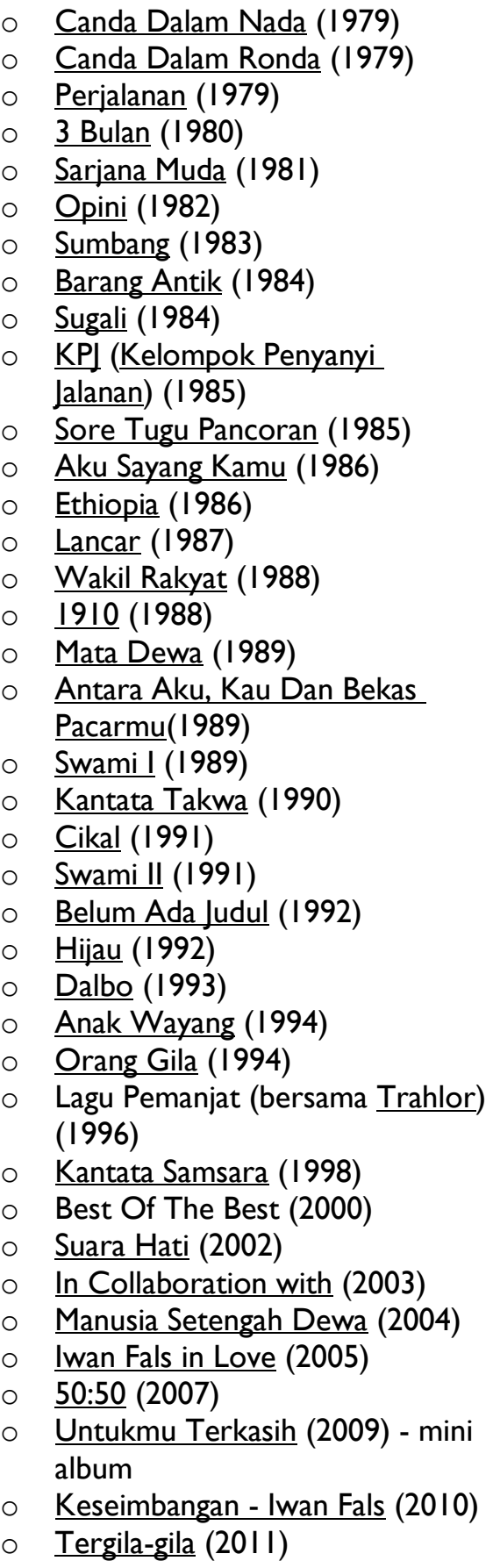

Compilation Album

$\begin{array}{cl}\circ & \text { Tragedi } \\ \circ & \text { Banjo \& Harmonika } \\ \circ & \text { Celoteh-celoteh } \\ \circ & \text { Celoteh-celoteh } 2 \\ \circ & \text { Country } \\ \circ & \text { Tembang Cinta (1990) } \\ \circ & \text { Akustik } \\ \circ & \text { Akustik Ke-2 (I997) }\end{array}$




\section{Acknowledgement}

I am grateful to Iwan Fals who agreed to be interviewed for this article.

\section{References}

Ahmad, T. A. (2010). Iwan Fals vs Oom Pasikom. Media Pendidikan Politik Alternatif [Iwan Fals vs. Oom Pasikom. An Alternative Media for Political Education]. Ombak

Ali, D. J. (2006). Membaca Isu Politik [Reading Political Issues]. LkiS.

Aning, F. (2005). 100 Tokoh yang Mengubah Indonesia [ 100 Figures Who Change Indonesia]. Narasi

Ashaf, A. F. (2006). Sikap Politik Pemerintah dalam Pewacanaan Musik Populer Tahun 80-an dan 90an. Jurnal Ilmu Sosial dan Ilmu Politik, 9(3),

Bodden, M. (2005). Rap in Indonesian Youth Music of the 1990s: Globalization", "Outlaw Genres," and Social Protest. Asian Music, 36(2), I-26

Fatimah \& Sukribo, M. (2009). DPR Uncensored. Bentang Pustaka

Harsono, A. (2002, October 1). Dewa dari Leuwinanggung. Andreasharsono.net. http://www.andreasharsono.net/2002/I0/dewadari-

leuwinanggung.html\#: :text=Andreas\%20Harson ०\%3A\%20Dewa\%20dari\%20Leuwinanggung

Hidayat, A. (n.d). Iwan Fals, the Rolling Stone Interview. Buku Ini Aku Pinjam. https://bukuiniakupinjam.blogspot.com/2007/05/i wan-fals-rolling-stone-interview.html

Hooker, V. M. (1999). Expression: Creativity despite Constraint. In Emmerson, D. K. (Ed.), Indonesia beyond Suharto: Polity, Economy, Society, Transition. Armonk

Lockard, C. A. (1996). Popular Musics and Politics in Modern Southeast Asia: A Comparative Analysis. Asian Music, 27(2), 149-199

Lockard, C. A. (1998). Dance of Life. Popular Music and Politics in Southeast Asia. University of Hawaii Press

Mandal, S. K. (2003). Creativity in Protest: Workers Arts and the recasting of Politics and Society in Indonesia and Malaysia. In Heryanto, A. (Ed.) Challenging authoritarianism in Southeast Asia. Routledge

Mukhyi, A. (2005). Iwan Fals. Tak Tahu Kapan Kisah Ini Akan Berakhir [Iwan fals: I Don't Know When This Story Will End]. Nuansa

Sen. K. \& Hill, D. (2000). Media, Culture and Politics in Indonesia. Oxford University Press
Sen. K. \& Hill, D. (2004). Global Industry, National Politics. Popular music in 'New Order' Indonesia. In Chun, A. et al. (Eds.), Refashioning pop music in Asia: Cosmopolitan flows, political tempos and aesthetic industries. Routledge

Shiaishi, S. (1997). Young Heroes. The Indonesian Family in Politics. Cornell University Southeast Study Program

Suseno, D. B. (2004). Nasionalisme Cinta Iwan Fals [Love Nationalism of Iwan Fals]. Kreasi Wacana Susilo, T. A. (2009). Iwan Fals. A-Plus Books.

I Ben Anderson wrote, "Over the past dozen years I have been accustomed to asking Indonesian youngsters who visit Cornell or come to study there this simple question: Who in Indonesia today do you admire and look up to? The common response is, first, bewilderment at the question, then a long scratching of the head, and finally a hesitant ... Iwan Fals. Isn't this rather terrifying? I don't mean that everyone can or should become a great man or woman. But I think that every man and woman can decide not to be a dwarf." See: Anderson, B. (1999) Indonesian Nationalism Today and in The Future. In Indonesia, No 67 (Apr 1999), Pp. I - II. Cornell: Southeast Asia Program Publications.

2 See Lockhart (1998) Dance of Life. Popular Music and Politics in Southeast Asia. Honolulu: University of Hawai'i Press

${ }^{3}$ See Time Magazine, April 29th, 2002

4 Mogi Darusman's album was the first and the last one. He was banned and not allowed to sing in Indonesia. See Mulyadi, M. (2009). Industri Musik Indonesia: Sebuah Sejarah (Indonesian Music Industry. A History). Bekasi: Koperasi Ilmu Sosial

${ }^{5}$ Emha Ainun Najib, commonly known as Cak Nun, is one of prolific writers in Indonesia. He is known as the poet who combines Islam and Javanese culture. This man had studied at the Islamic boarding school Gontor and also known as one of the leaders of reformasi movement, with Amien Rais, Nurcholish Madjid and Abdurrahman Wahid (Gus Dur).

${ }^{6}$ Eko Tunas is a writer who comes from Tegal, Central Java. He became a writer, painter, and theater director after he studied in junior high school. Today he lives in Semarang, the capital city of Central Java. His writings were published by several mass media in Indonesia

${ }^{7}$ EH Kartanegara is a writer who was born in Pekalongan. $\mathrm{He}$ is known for his ideas to produce musical poetry. He was a Tempo journalist, and also the founding father of Republika, daily newspaper

8 Taufiq Ismail is an Indonesian poet and author, devout Muslim, and a committed activist. Ismail figured prominently in Indonesian literature of the postSukarno period and is considered one of the pioneers of the "Generation of '66"

9 Late Ramadhan K.H. was a famous author. He wrote Kuantar ke Gerbang (I Take You to the Gate), the love 
story of Presiden Soekarno with Inggit Ganarsih. He also became an author of Presiden Soeharto biography, Pikiran, Ucapan dan Tindakan Saya (My Thinking, My Saying, and My Action)

10 Wing Karjo is a poet and also a lecturer at the University of Padjadjaran, Bandung. He pursued his doctorate at the University of Paris and wrote a dissertation about the resistance aspects in the poems of Sitor Situmorang, Indonesian poet

11 The best article about Rhoma Irama can be seen in Frederick, W. H. (1982) Rhoma Irama and the Dangdut Style: Aspects of Contemporary Indonesian Popular Culture. Indonesia 34 (October 1982): I03-130

12 According to Wikipedia and rajadangdut.com

13 Indonesian Record Museum (MURI) noted that Iwan Fals concert on June 23, 1990, at the Bung Karno Stadium, was the most widely attended concert audience. Muri estimated that concert was attended more than 150,000 people. This amount exceeds the capacity of the stadium that only 90,000 people.

14 See: Indonesian in Focus: (http://www.planetmole.org/daily/indonesians-infocus-iwan-fals.html)

15 Arief Budiman (born January 3, 1941 in Jakarta), also known as Soe Hok Djin is the older brother of Soe Hok Gie. He graduated from Kolese Kanisius, a Jesuit high school, and then University of Indonesia where he earned a bachelor degree in psychology in 1968. In 1980, he earned his Ph.D. in sociology from Harvard University, USA. He is a Chinese Indonesian sociologist and was a lecturer at the Universitas Kristen Satya Wacana, Salatiga, Indonesia until 1996. From 1997 until the time of this writing, he is a professor in Indonesian studies in University of Melbourne, Australia. See: http://en.wikipedia.org/wiki/Arief_Budiman

16 Budiman Sudjatmoko is known as the leader of leftist student movement in 1998. He became a chairman of People's Democratic Association (Perhimpunan Rakyat Demokratik). In July 1996, he founded the People's Democratic Party (PRD) and led street demonstration in Jakarta. Now he is a member of Indonesian representatives

17 Sri Bintang Pamungkas was known as the leader of Democratic Union Party of Indonesia (PUDI), the opposition political party that was established in the New Order era. He called himself one of Soeharto's political enemies. The party was then banned by the government. After the reform, he failed to become a member of parliament and ended his political career

18 Khofifah Indar Parawansa is an important figure in the women organization of Nahdatul Ulama (NU), the largest Muslim organization in Indonesia. He became Minister of Women Empowerment in the National Unity Cabinet under President Gus Dur

19 Franz Magnis Suseno was originally called Count von Magnis before becoming a Jesuit in 1955. He studied Marxism to combat it as an enemy of the faith. $\mathrm{He}$ settled in Indonesia in 1961 and became an Indonesian citizen in 1977 adding the name "Suseno" to his own. Although anti-communist he is concerned with social justice and issues about how "The rich get richer, while the poor get poorer." He heads the Driyarkara School of Philosophy and is a noted social and political analyst in his nation. In Indonesia he is often called Romo, father, Magnis.[2] In 2007 he turned down the Bakrie
Award because of a Sidoarjo mud flow.[3] He received a Habibie award for interfaith dialogue.See http://en.wikipedia.org/wiki/Franz_Magnis-Suseno

20 Zulkiflee SM Anwar Ulhaque (born May 15, 1962), better known as Zunar to Malaysians, is a cartoonist for online news website, Malaysiakini. He is the most important cartoonist in Malaysia. His books were banned by the government. He has also been detained by police for his insulting cartoons of the Prime Minister Mahathir Mohammad

21 See Mandal, S.K. (2003) Creativity in protest: art workers and the recasting of politics and society in Indonesia and Malaysia. In Heryanto, A. and Mandal, S. K (2003) Challenging Authoritarianism in Southeast Asia. London: Routledge.

22 Iwan Fals: "Saya bermimpi tak ada tentara." (I have a dream that there are no soldiers). In Tempo I0/XXXIII, May 3th, 2004.

23 "Ayah saya seorang tentara. Tapi ayah saya bukan tentara yang galak. Bahkan, ibu saya lebih galak dibanding ayah saya. Nah, saya ingin tentara yang lain juga begitu."

24 Sewaktu kecil, saya sudah punya piano. Di rumah terkadang berisik, kalau sedang waktu salat sering dimarahi. Orangtua saya ketat dalam mendidik soal agama. Saya pernah mendapat juara azan tingkat DKI ketika masih SD."

25 "Saya memang anak tentara. Saya cukup disiplin. Saya memegang sabuk hitam karate. Kalau tak disiplin, tak mungkin menyandang sabuk hitam. Orangtua saya selalu mendukung. Bagi mereka, sepanjang saya yakin benar, maka lakukan saja. Yang ibu saya sesali, mengapa saya tidak menjadi insinyur. Setelah ibu melihat sekarang, saya sangat disayangi."

26 The title of song is "Rindu Tebal" (The thick longing). In Sugali (1984).

27 See Shiraishi, S. (1997). Young Heroes. The Indonesian Family in Politics. Cornell: Southeast Asian Studies Program

28 "Saham Kosong itu Biasa", In Tempo, 05/XXVIII, April 06, 1999

${ }^{29}$ Cendana is the other name of Suharto's family. Because Soeharto lived at Cendana Street at Jakarta.

30 "Dibesarkan Sigit, Tommy, dan nama-nama besar. In Tempo, 05/XXVIII, April 6, 1999

31 "Setiap lagu datang begitu saja. Bagi saya, lagu adalah panggilan. Saya pernah jadi seorang murid sekolah, makanya bisa bercerita tentang guru. Banyak yang tanya, apakah Oemar Bakrie tokoh real? Awalnya, saya mau kasih nama Abdul Gani. Tapi karena ada teman saya yang nama Abdul Gani, makanya dia memprotes. Hahaha.. Pesannya apa? Dulu saya tidak membuat pesan apa-apa. Saya buat lagu saja. Setelah lagu itu beredar, saya coba buat analisaanalisa, rupanya ternyata ada cerita kesederhanaan, keluguan, atau yang lain."

32"Waktu itu saya diinterogasi selama I 4 hari di Pekanbaru. Saya dianggap menghina kepala negara. karena lagu Demokrasi Nasi dan Mbak Tini. Lagu ini cerita tentang pelayan warung kopi. dan suaminya Suhardi. Tapi waktu dipanggung, saya ubah jadi Suharto. Lagu itu tentang sopir dan pelayan warung kopi. Sopir ini mantan pencuri. Mereka ingin bentuk rumah tangga. Tapi sopir kembali jadi pencuri. Istrinya kembali jadi pelacur. Waktu itu saya masih muda. Mungkin saja saya terpengaruh sama nama Suharto yang di televisi. Waktu itu saya bingung jawabnya. Saya malah menangis." 
33"Banyak yang menganggap lagu ini adalah kependekan dari lagu Benci Soeharto. Apa betul benci? Tidak. Cuma bosan saja. karena waktu itu terlalu lama. Saya tidak mengerti politik. Saya hanya ingin ada suasana yang baru. Mungkin juga ini jadi santapan pers untuk dibesar-besarkan. Waktu itu ada fenomena real estate dan muncul keluargakeluarga baru yang tinggal di perumahan. Waktu itu, KKN hal biasa. Mengapa saya pakai nama Bento? Karena saya pikir tidak ada yang bernama Bento. Saya bisa saja pakai nama Andi, Budi, atau nama lain. Walaupun ada pemain bola dari Timor Leste yang namanya Bento. Belakangan muncul plesetan, misalnya Benci Soeharto, Benci Tommy, atau Benny Soeharto."

34 "Lagu Bongkar diciptakan waktu saya tinggal di Condet tahun 1989. Apa pesannya? Waktu itu ada cerita tentang Kedungombo. Saya agak tersentuh. Kedingombo adalah waduk yang dibentuk dengan menenggelamkan desa. Ada juga kasus Kacakpiring dan Way Jepara di Lampung yang banyak korban. Waktu itu saya kembangkan sama Jabo. Akhirnya muncul kata "Penindasan serta kesewenangwenangan."

\section{Notes on Authors}

Muhammad Yusran Darmawan is a blogger, columnist, anthropologist, researcher, writer, and social media activist. His interests include sociocultural issues, politics, history, humanity, and social media. This article can be found also at his personal blog: www.timur-angin.com. E-mail: yusrandarmawan@gmail.com. 